\title{
NON-MINERAL INORGANIC CONSTITUENTS OF BUKIT ASAM COAL NATURE AND MODE OF OCCURRENCE
}

\section{KONDISI ALAMI DAN KEBERADAAN KOMPONEN NON-MINERAL INORGANIK DARI BATUBARA BUKIT ASAM}

\author{
Rita Susilawati \\ Centre for Geological Resources \\ Jl. Soekarno-Hatta No. 444 Bandung, Indonesia \\ Email: wink2proud@gmail.com
}

\begin{abstract}
The nature and mode of occurrence of the non-mineral inorganic fractions in coal from the Bukit Asam coalfield South Sumatra Basin Indonesia were analysed using a combination of selective leaching, low temperature ashing, XRD, XRF and electron micropobe techniques. Geologically the rank of coal at Bukit Asam was influenced by igneous intrusion. Fourteen coal samples were used in this study. Samples are chosen to represent different rank levels as well as seam horizons. The inorganic elements, in the form of dissolved salts, exchangeable ions and organometallic complexes, although present in small proportions, contribute significantly to the mineral matter components of Bukit Asam low rank coal. Electron microprobe analysis showed small but significant concentrations of inorganic elements ( $\mathrm{Al}, \mathrm{Ca}$ and $\mathrm{Fe}$ ) occurring in the individual macerals in two sub bituminous and twosemi anthracite samples. There is a tendency for some of the elements, particularly Ca and Al to be lost from the organic matter with rank advance. The concentrations of elements indicated by the microprobe are relatively in good agreement with the levels of element mobility indicated by selective leaching of the same whole-coal samples. The results of this study also suggest that non-mineral inorganic was likely act as a precursor for the reactions resulting in the formation of new minerals in the high rank coals at Bukit Asam.
\end{abstract}

Keywords : non-mineral inorganic, coal, Bukit Asam

\section{SARI}

Tulisan ini membahas keberadaan non-mineral inorganic komponen pada batubara Bukit Asam di cekungan Sumatra Selatan. Secara geologi, peringkat batubara Bukit Asam dipengaruhi oleh intrusi batuan beku. Penelitian dilakukan terhadap 14 conto batubara Bukit Asam dengan menggunakan gabungan metoda selective leaching, low temperature ashing, $X R F, X R D$ dan electron micropobe. Conto batubara diambil dari beberapa lapisan dan dipilih untuk mewakili berbagai peringkat batubara yang terdapat di Bukit Asam. Non-mineral inorganik pada batubara Bukit Asam ditemukan dalam bentuk garam terlarut (dissolved salts), ion yang bisa berpindah (exchangeable ions) dan senyawa logam organik (organometallic complexes). Walaupun hadir dalam prosentasi yang kecil, non-mineral inorganic merupakan komponen mineral matter yang cukup signifikan pada batubara sub bituminus yang diteliti. Hasil studi juga menunjukkan keberadaan unsur inorganik (Al, Ca dan $\mathrm{Fe}$ ) yang berasosiasi dengan komponen organik batubara (maseral). Beberapa unsur terutama Ca dan Al memiliki kecenderungan untuk menghilang dari maseral seiring dengan bertambahnya peringkat batubara. Secara umum hasil studi ini menunjukkan kesesuaian antara hasil analisa microprobe dan selective leaching. Disamping itu hasil studi ini juga mengindikasikan peranan non-mineral inorganik pada pembentukan mineral-mineral baru pada batubara Bukit Asam peringkat tinggi.

Kata kunci : non-mineral inorganic, batubara, Bukit Asam 


\section{INTRODUCTION}

The mineral matter present in coal is a result of the combination of geological processes that occur during coal formation. The term "mineral matter" covers three types of inorganic material present in coal (Ward, 2002), which are: (i) discrete crystalline mineral particles, (ii) dissolved ions and other inorganic components in the pore water or surface water of the coal, and (iii) inorganic elements combined within the organic compounds of the coal macerals. While crystalline mineral particles make up almost the entire mineral matter in higher rank coals, inorganic elements in the form of dissolved salts, exchangeable ions and organometallic complexes contribute significantly to the mineral matter components and ash formation of lower rank coals (Kiss and King, 1977; Miller and Given, 1978; Benson and Holm, 1985; Ward, 1991, 1992)

Apart for the high rank coal, which occurs locally due to the presence of igneous intrusions, most of the coal at Bukit Asam can be categorized as a low rank coal. The mineral matter of coal at Bukit Asam has been discussed in Susilawati and Ward (2002). This paper focuses on the nature and mode of occurrence of the nonmineral inorganic fractions in the lower rank coals of the Bukit Asam coalfield South Sumatra Basin Indonesia, as indicated by selective leaching tests combined with chemical analysis of the different leachates.

\section{COAL IN BUKIT ASAM AREA}

The Bukit Asam coalfield is part of the South Sumatra Basin. This basin is one of several Tertiary coal basins of Indonesia that form a major coal and hydrocarbon producing area situated in South Sumatra Province. The coal geology of the South Sumatra Basin has been discussed in some detail by several authors, such as de Coster (1974), Koesoemadinata (1978), Matasak and Kendarsi (1980) and Hutchison (1996). Authors such as Stalder (1976) and Pujobroto (1997) have discussed the geology of Bukit Asam, with particular emphasis on the occurrence of coal in the area.

Coal at Bukit Asam belongs to Muaraenim formation. The coal is formed in the regressive phase of the Neogene depositional cycle (de Coster,. 1974). During deposition of the Muara Enim Formation, the tectonic setting of the South Sumatra Basin produced a quite regular pattern of coal deposition in respect of thickness, ash and split pattern, caused by exceptionally regular subsidence coupled with the right type of climate (Stalder, 1976). Coalification in Muara Enim Formation was controlled much more by burial depth variations, with a geothermal gradient of constant value throughout the basin, than by variations in the value of geothermal gradient (Stalder,. 1976). As such, on a regional scale, the coal rank distribution was controlled by the burial variations during the basinal stage (Stalder,. 1976). The large gradient encountered in some areas is due to the effect of the igneous intrusions (Stalder,. 1976; Susilawati and Ward., 2002). The stratigrafi of coal at Bukit Asam area is appeared in Figure 1.

Three economic coal-bearing intervals are identified in the study area, which are from top to bottom: the Mangus (A seam), the Suban ( $B$ seam) and the Petai ( $C$ seam). This study will only focus on $B$ and $C$ seams. 


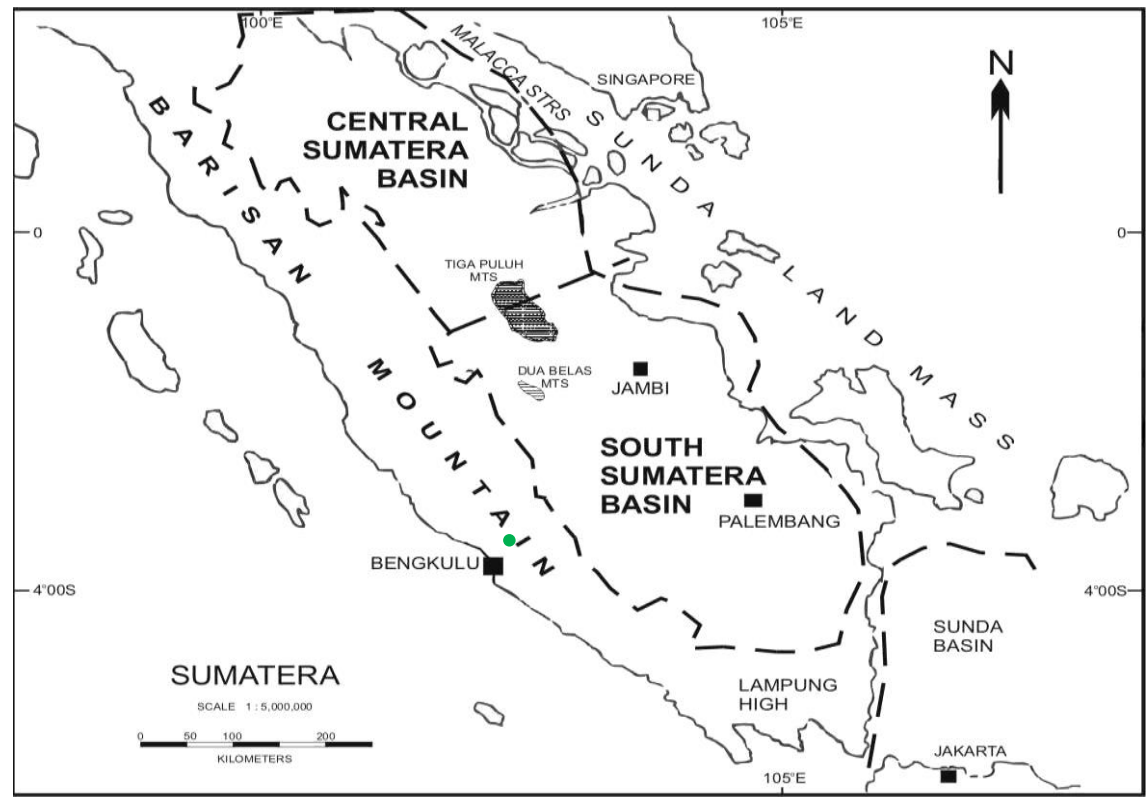

a)

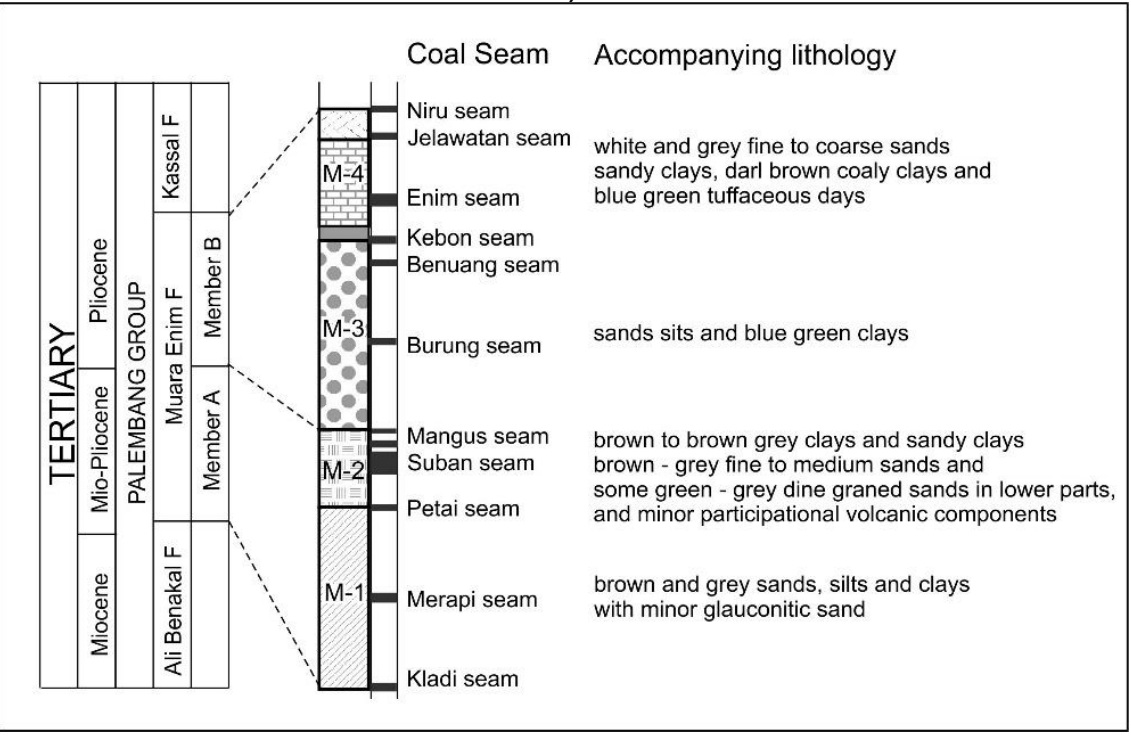

b)

Figure 1. Location of the study area: a) Coal sampling (green dot) at Bukit Asam coalfield; b) Coal stratigraphy of Bukit Asam area. Stratigraphy of the coal seam is modified from Amijaya and Littke (2006)

\section{METHODS}

\section{Sampling}

Fourteen coal samples were used in this study (Table 1). Ten samples were subbitumibous coal that have been collected from exposures of the open cut mine workings of Air laya pit in the Bukit Asam

different rank levels and different seam horizons. Those samples were examined coal field and collected on a ply-by-ply basis (Table 1, Figure 2). Those samples were representing part of the vertical section through the $B$ and $C$ seam. Selective leaching analysis was used to investigate the elements occurring in different ways within the non-mineral inorganic fraction in those samples. The other four coals were grab samples (Table 1 , Figure 2) and chosen to represent to evaluate the inorganic elements occurring in the individual macerals both in 


\section{MAKALAH ILMIAH}

lower and higher rank coals, using electron micropobe techniques.

Table 1. Coal samples used in this study(For sampling location, see Figure 2)

\begin{tabular}{|c|c|c|c|}
\hline No & $\begin{array}{l}\text { Samples } \\
\text { number }\end{array}$ & $\begin{array}{l}\text { Thickness } \\
\text { (m) }\end{array}$ & $\begin{array}{l}\text { Rank } \\
\text { (Rv } \\
\text { max) }\end{array}$ \\
\hline \multicolumn{4}{|c|}{ Station 4} \\
\hline 1 & B1-1 & 1.5 & 0.45 \\
\hline 2 & B3-1 & 1.2 & \\
\hline 3 & B4-1 & 1.1 & \\
\hline 4 & B5-1 & 1.3 & \\
\hline 5 & B6-1 & 1 & \\
\hline \multicolumn{4}{|c|}{ Station 12} \\
\hline 6 & C39-1 & 1 & 0.49 \\
\hline 7 & C40-1 & 1 & \\
\hline 8 & C41-1 & 1 & \\
\hline 9 & C42-1 & 1 & \\
\hline 10 & C43-1 & 1 & \\
\hline \multicolumn{4}{|c|}{$\begin{array}{l}\text { Grab } \\
\text { samples }\end{array}$} \\
\hline 11 & Frid 1 & na & 0.49 \\
\hline 12 & Frid 3 & na & 2.3 \\
\hline 13 & Frid 4 & na & 0.54 \\
\hline 14 & Frid 5 & na & 2.45 \\
\hline
\end{tabular}

Notes: Chemical analysis of samples from station 4 and 12 showed that coals are sub bituminous in rank. Assuming all samples from the same plies have similar rank, reflectance analysis were only done to the first samples from the top of the plies (B1-1 and C39-1). 


\section{MAKALAH ILMIAH}

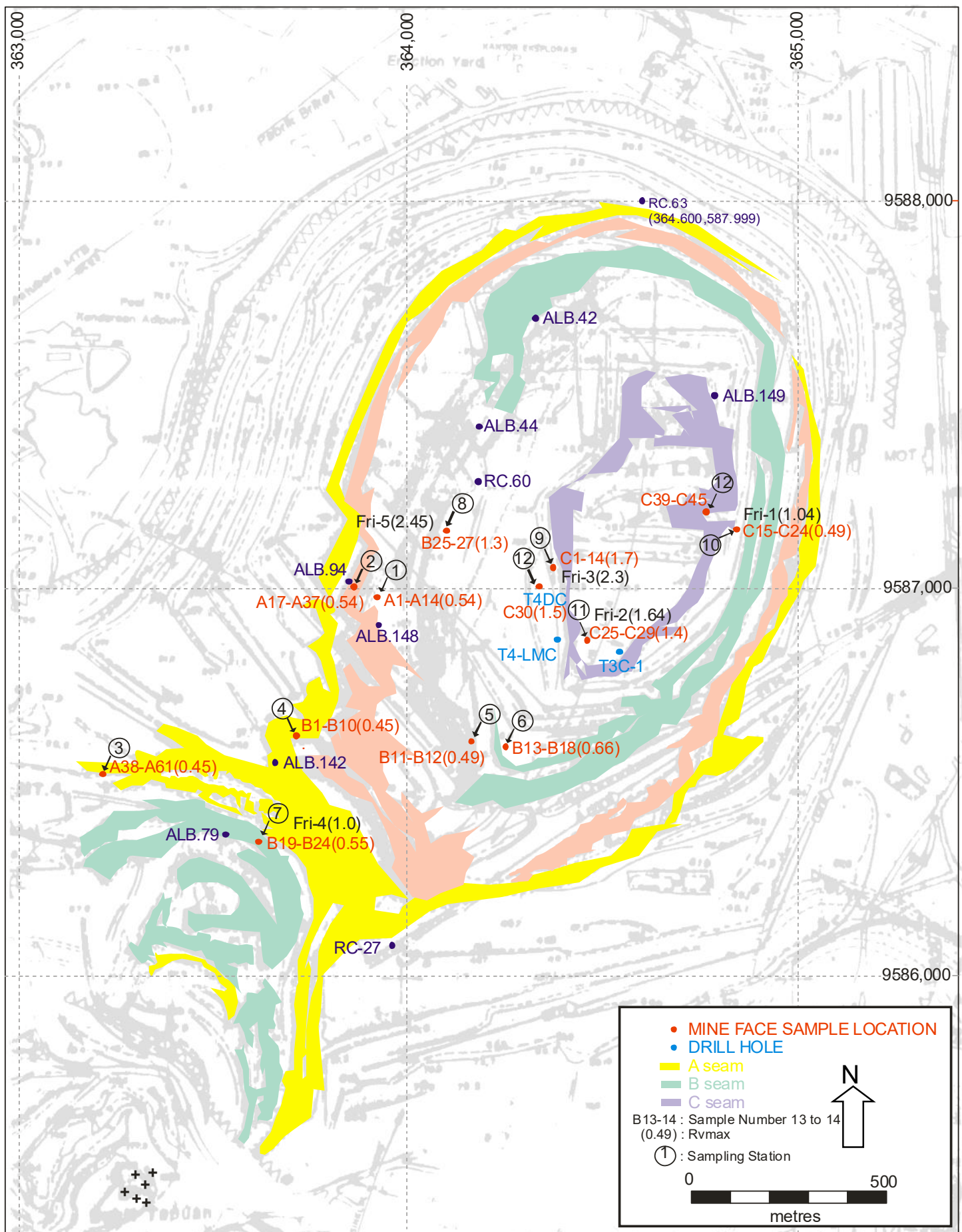

Figure 2. Sampling location at Airlaya pit Bukit Asam coalfield South Sumatra Basin

\section{Analysis}

In this study, a selective leaching process was used to investigate the elements occurring in different ways within the nonmineral inorganic fraction. The selective leaching process was based on immersing the coal successively in water, ammonium acetate and hydrochloric acid (figure 3). Detailed of the analysis procedures can be found in Susilawati (2002). The elements present in the three leachate solutions from each coal sample were analysed using inductively coupled plasma atomic emission spectrophotometry (ICP-AES), after all of the solutions had been diluted 
to a constant volume. The results were processed to determine the total amount of each element leached from each coal sample as a proportion of the total amount of that element in the same sample, determined by XRF analysis of the raw (untreated) coal.

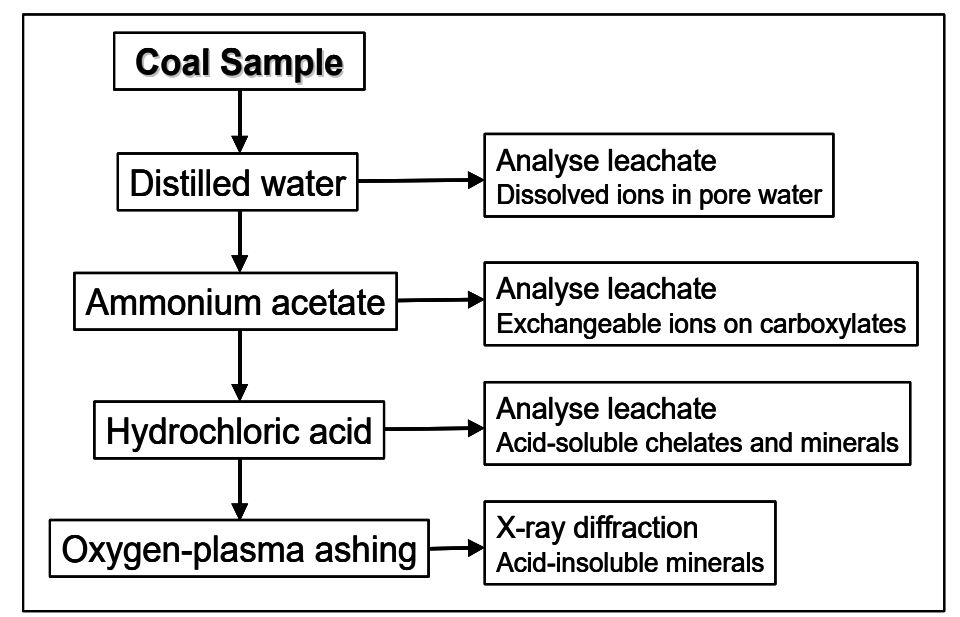

Figure 3. Flow sheet showing selective leaching process

Low temperature oxygen-plasma ashing (LTA), as described in Susilawati and Ward (2002) was used to remove the organic fraction of coal samples in order to facilitate analyses of the minerals associated with the coal. The mineralogy of the residue from each coal sample was then analysed using X-ray diffraction (XRD) methods, while the bulk mineralogy from the resulting diffractograms was quantified using the Rietveld based Siroquant data processing system (Taylor, 1991; Ward et al., 1999).

Chemical analysis of major elements in coal samples was carried out by X-ray fluorescence (XRF) method. Since insufficient ash was available from each coal sample, the fused borosilicate disk techniques (Norrish and Chappell., 1977) could not be used. As such, pressed powder pellets were prepared. Detailed of XRF analysis can be found in Susilawati and Ward (2002).

The elemental composition of the organic components in Bukit Asam coal was analysed using electron micropobe technique following method described in Ward and Gurba (1999). The analysis focused to the variations associated with rank advance. A total of four coal samples were analysed by this method.

\section{RESULTS AND DISCUSSION}

\section{Element Mobility}

Six significant elements were released from the samples studied by the combination of water washing, ammonium acetate and hydrochloric acid. The proportions of those elements in the different leachates were recalculated to determine the percentage of each element leached as a fraction of the total that originally present in each coal sample based on raw coal XRF analysis (Table 2 and 3). Although the concentration of mobile elements in Bukit Asam coal is very low, their modes of occurrence can be seen clearly which will be discussed more fully in the explanation below.

$\mathrm{Al}$ and $\mathrm{Si}$ are the major constituents of the mineral matter in the coals studied, occurring mainly in clay minerals and quartz (Susilawati and Ward, 2002). XRF analysis of the raw coal showed that $\mathrm{Al}_{2} \mathrm{O}_{3}$ and $\mathrm{SiO}_{2}$ together account for about 30$50 \%$ (Table 2). The analytical results suggest that only a small proportion of the 
aluminium in the Bukit Asam coal samples is present in mobile form (Figure 3 ). This element is almost insoluble in water and ammonium acetate. Small but significant concentrations of aluminium, however are also soluble in hydrochloric acid. Other occurrences of significant acid soluble aluminium have been reported in Victorian brown coals by Kiss and King (1979), and in Northern Thailand coals by Ward (1991). Si in the Bukit Asam coals was essentially insoluble in all of the leaching solutions with only very small concentration of mobile $\mathrm{Si}$ was released from the coals by the different leaching processes

Table 2. Element concentrations released from coal samples of the B seam treated by different leaching solutions

\begin{tabular}{|c|c|c|c|c|c|c|c|c|}
\hline \multirow[t]{2}{*}{$\begin{array}{l}\text { Sample } \\
\text { Code }\end{array}$} & \multirow[t]{2}{*}{$\begin{array}{l}\text { Major } \\
\text { oxide } \\
\text { by XRF } \\
\text { analysis }\end{array}$} & \multicolumn{3}{|c|}{$\begin{array}{l}\text { Element concentration } \\
\text { released from coal } \\
\text { treated by different } \\
\text { leaching solution (ppm) }\end{array}$} & \multicolumn{3}{|c|}{$\begin{array}{l}\text { Element released from } \\
\text { coal treated } \begin{array}{r}\text { by } \\
\text { different } \\
\text { solution (\%) }\end{array}\end{array}$} & \multirow[t]{2}{*}{$\begin{array}{l}\text { Total } \\
\text { Mobile } \\
(\%)\end{array}$} \\
\hline & & Water & Acetate & Acid & Water & Acetate & Acid & \\
\hline \multicolumn{9}{|c|}{ Aluminum } \\
\hline B1-1 & 0.68 & 0.53 & 0.04 & 21.82 & 0.29 & 0.02 & 12.13 & 12.45 \\
\hline B3-1 & 0.84 & 0.33 & 0.03 & 13.92 & 0.15 & 0.02 & 6.29 & 6.45 \\
\hline B4-1 & 0.32 & 0.52 & 0.04 & 16.32 & 0.61 & 0.05 & 19.28 & 19.94 \\
\hline B5-1 & 0.69 & 0.54 & 0.03 & 15.24 & 0.29 & 0.02 & 8.3 & 8.61 \\
\hline B6-1 & 0.47 & 0.55 & 0.03 & 13.19 & 0.44 & 0.02 & 10.52 & 10.98 \\
\hline \multicolumn{9}{|l|}{ Calcium } \\
\hline B1-1 & 0.28 & 0.64 & 32.55 & 26.38 & 0.65 & 32.99 & 26.74 & 60.37 \\
\hline B3-1 & 0.23 & 0.33 & 31.69 & 23.67 & 0.4 & 38.54 & 28.79 & 67.73 \\
\hline B4-1 & 0.19 & 1 & 40.75 & 26.33 & 1.45 & 59.06 & 38.16 & 98.67 \\
\hline B5-1 & 0.25 & 0.54 & 30.98 & 22.93 & 0.6 & 34.66 & 25.66 & 60.92 \\
\hline B6-1 & 0.22 & 1.34 & 36.7 & 43.51 & 1.68 & 46.03 & 54.58 & 102.29 \\
\hline \multicolumn{9}{|l|}{ Iron-1 } \\
\hline B1-1 & 0.07 & 0.02 & $\mathrm{Bdl}$ & 14.19 & 0.08 & 0 & 56.39 & 56.47 \\
\hline B3-1 & 0.09 & 0.01 & $\mathrm{Bdl}$ & 14.94 & 0.02 & 0 & 49.71 & 49.73 \\
\hline B4-1 & 0.07 & 0.06 & $\mathrm{Bdl}$ & 15.63 & 0.26 & 0 & 66.75 & 67 \\
\hline B5-1 & 0.09 & 0.02 & $\mathrm{Bdl}$ & 21.11 & 0.06 & 0 & 68.64 & 68.7 \\
\hline B6-1 & 0.1 & 0.06 & $\mathrm{Bdl}$ & 19.24 & 0.17 & 0 & 55.05 & 55.22 \\
\hline \multicolumn{9}{|l|}{ Sodium } \\
\hline B1-1 & 09 & 16.18 & 20.89 & 2.13 & 50.58 & 65.3 & 6.66 & 122.53 \\
\hline B3-1 & 0.08 & 16.57 & 21.08 & 2.31 & 53.03 & 67.46 & 7.39 & 127.88 \\
\hline B4-1 & 0.07 & 15.84 & 15.92 & 1.77 & 63.55 & 63.87 & 7.1 & 134.53 \\
\hline B5-1 & 0.07 & 16.21 & 14.62 & 1.12 & 61.37 & 55.35 & 4.24 & 120.97 \\
\hline B6-1 & 0.11 & 13.75 & 10.11 & 1.04 & 35.2 & 25.88 & 2.65 & 63.74 \\
\hline \multicolumn{9}{|c|}{ Magnesium } \\
\hline B1-1 & 0.03 & 0.34 & 16.98 & 5.19 & 3.58 & 181.67 & 55.53 & 240.79 \\
\hline B3-1 & 0.03 & 0.31 & 15.75 & 5.31 & 3.48 & 174.13 & 58.71 & 236.31 \\
\hline B4-1 & 0.04 & 0.75 & 19.07 & 5.87 & 7.11 & 158.11 & 48.67 & 213.89 \\
\hline B5-1 & 0.04 & 0.72 & 16.64 & 6.03 & 6 & 137.95 & 50.03 & 193.98 \\
\hline B6-1 & 0.08 & 0.87 & 18.13 & 5.82 & 3.48 & 72.44 & 23.25 & 99.17 \\
\hline \multicolumn{9}{|l|}{ Silicon } \\
\hline B1-1 & 0.59 & 0.44 & 0.13 & 0.55 & 0.32 & 0.09 & 0.4 & 0.81 \\
\hline B3-1 & 0.73 & 0.28 & 0.08 & 0.48 & 0.17 & 0.05 & 0.28 & 0.5 \\
\hline B4-1 & 0.35 & 0.45 & 0.21 & 0.54 & 0.55 & 0.26 & 0.66 & 1.46 \\
\hline
\end{tabular}




\section{MAKALAH ILMIAH}

\begin{tabular}{lllllllll} 
B5-1 & 0.6 & 0.5 & 0.19 & 0.71 & 0.36 & 0.14 & 0.51 & 1 \\
\hline B6-1 & 0.36 & 0.39 & 0.2 & 0.13 & 0.46 & 0.24 & 0.15 & 0.85
\end{tabular}

Notes: Concentrations released are expressed as percentages of the total element in the dry coal, as indicated in oxide terms by whole coal XRF analysis in the B seam.

Table 3. Element concentrations released from coal samples of the $C$ seam treated by different leaching solutions

\begin{tabular}{|c|c|c|c|c|c|c|c|c|}
\hline \multirow[t]{2}{*}{$\begin{array}{l}\text { Sample } \\
\text { Code }\end{array}$} & \multirow{2}{*}{$\begin{array}{l}\text { Major } \\
\text { oxide } \\
\text { By XRF } \\
\text { analysis }\end{array}$} & \multicolumn{3}{|c|}{$\begin{array}{l}\text { Element concentration } \\
\text { in leaching solution } \\
(\mathrm{ppm})\end{array}$} & \multicolumn{3}{|c|}{$\begin{array}{l}\text { Percent of element } \\
\text { leached from coal }\end{array}$} & \multirow{2}{*}{$\begin{array}{l}\text { Total } \\
\text { mobile } \\
(\%)\end{array}$} \\
\hline & & Water & Acetate & Acid & Water & Acetate & Acid & \\
\hline \multicolumn{9}{|c|}{ Aluminum } \\
\hline C39-1 & 1.27 & 0.84 & Bdl & 2.65 & 0.25 & 0 & 0.79 & 1.04 \\
\hline C40-1 & 1.36 & 0 & $\mathrm{Bdl}$ & 1.57 & 0 & 0 & 0.44 & 0.44 \\
\hline C41-1 & 0.96 & 0.07 & Bdl & 3.23 & 0 & 0 & 1.27 & 1.27 \\
\hline C42-1 & 0.74 & bdl & Bdl & 1.98 & 0 & 0 & 1.01 & 1.01 \\
\hline C43-1 & 0.69 & 0.39 & Bdl & 4.65 & 0.21 & 0 & 2.53 & 2.74 \\
\hline \multicolumn{9}{|c|}{ Calcium } \\
\hline C39-1 & 0.14 & 0.47 & 16.85 & 8.94 & 0.94 & 33.66 & 17.86 & 52.46 \\
\hline C40-1 & 0.15 & 11.15 & 8.29 & 3.73 & 20.52 & 15.26 & 6.86 & 42.64 \\
\hline C41-1 & 0.18 & 11.66 & 5.54 & 3.94 & 18.01 & 8.56 & 6.09 & 32.66 \\
\hline C42-1 & 0.14 & 6.88 & 7.64 & 3.39 & 13.75 & 15.26 & 6.77 & 35.78 \\
\hline C43-1 & 0.17 & 0.69 & 13.65 & 8.64 & 1.15 & 22.86 & 14.46 & 38.47 \\
\hline \multicolumn{9}{|l|}{ Iron } \\
\hline C39-1 & 0.05 & bdl & $\mathrm{Bdl}$ & 7.68 & 0 & 0 & 46.75 & 46.75 \\
\hline C40-1 & 0.17 & bdl & Bdl & 25.67 & 0 & 0 & 43.71 & 43.71 \\
\hline C41-1 & 0.24 & 1.4 & Bdl & 40.3 & 1.64 & 0 & 47.25 & 48.89 \\
\hline C42-1 & 0.18 & bdl & Bdl & 23.06 & 0 & 0 & 37.07 & 37.07 \\
\hline C43-1 & 0.09 & bdl & Bdl & 15.12 & 0 & 0 & 50.9 & 50.9 \\
\hline \multicolumn{9}{|l|}{ Sodium } \\
\hline C39-1 & 0.05 & 5.43 & 5.94 & 2.55 & 29.79 & 32.59 & 13.99 & 76.37 \\
\hline C40-1 & 0.06 & 8.89 & 3.52 & 2.25 & 40.48 & 16.04 & 10.25 & 66.77 \\
\hline C41-1 & 0.07 & 9.13 & 3.38 & 2.34 & 36.63 & 13.56 & 9.37 & 59.56 \\
\hline C42-1 & 0.07 & 9.73 & 4.03 & 2.25 & 35.83 & 14.82 & 8.29 & 58.94 \\
\hline C43-1 & 0.07 & 8.85 & 6.58 & 2.6 & 33.51 & 24.91 & 9.84 & 68.26 \\
\hline \multicolumn{9}{|c|}{ Magnesium } \\
\hline C39-1 & 0.02 & 0.19 & 5.79 & 2.02 & 3.15 & 96.02 & 33.42 & 132.59 \\
\hline C40-1 & 0.02 & 4.1 & 2.21 & 0.69 & 71.57 & 38.58 & 11.96 & 122.11 \\
\hline C41-1 & 0.01 & 4.21 & 1.48 & 0.48 & 77.58 & 49.09 & 15.75 & 142.42 \\
\hline C42-1 & 0.01 & 3.01 & 2.07 & 0.58 & 58.73 & 40.29 & 11.26 & 110.27 \\
\hline C43-1 & 0.01 & 0.34 & 4.87 & 1.88 & 7.52 & 107.57 & 41.57 & 156.66 \\
\hline \multicolumn{9}{|l|}{ Silicon } \\
\hline C39-1 & 1.35 & 1.2 & 0.44 & 0.49 & 0.38 & 0.14 & 0.16 & 0.68 \\
\hline C40-1 & 1.59 & 0.16 & 0.2 & 0.57 & 0.04 & 0.05 & 0.15 & 0.25 \\
\hline C41-1 & 0.86 & 0.1 & 0.1 & 0.27 & 0.05 & 0.05 & 0.13 & 0.23 \\
\hline C42-1 & 0.74 & 0.04 & 0.12 & 0.22 & 0.03 & 0.07 & 0.13 & 0.22 \\
\hline C43-1 & 0.65 & 0.59 & 0.14 & 0.4 & 0.39 & 0.09 & 0.26 & 0.75 \\
\hline
\end{tabular}

Notes: Concentrations released are expressed as percentages of the total element in the dry coal, as indicated in oxide terms by whole coal XRF analysis in the $\mathrm{C}$ seam 

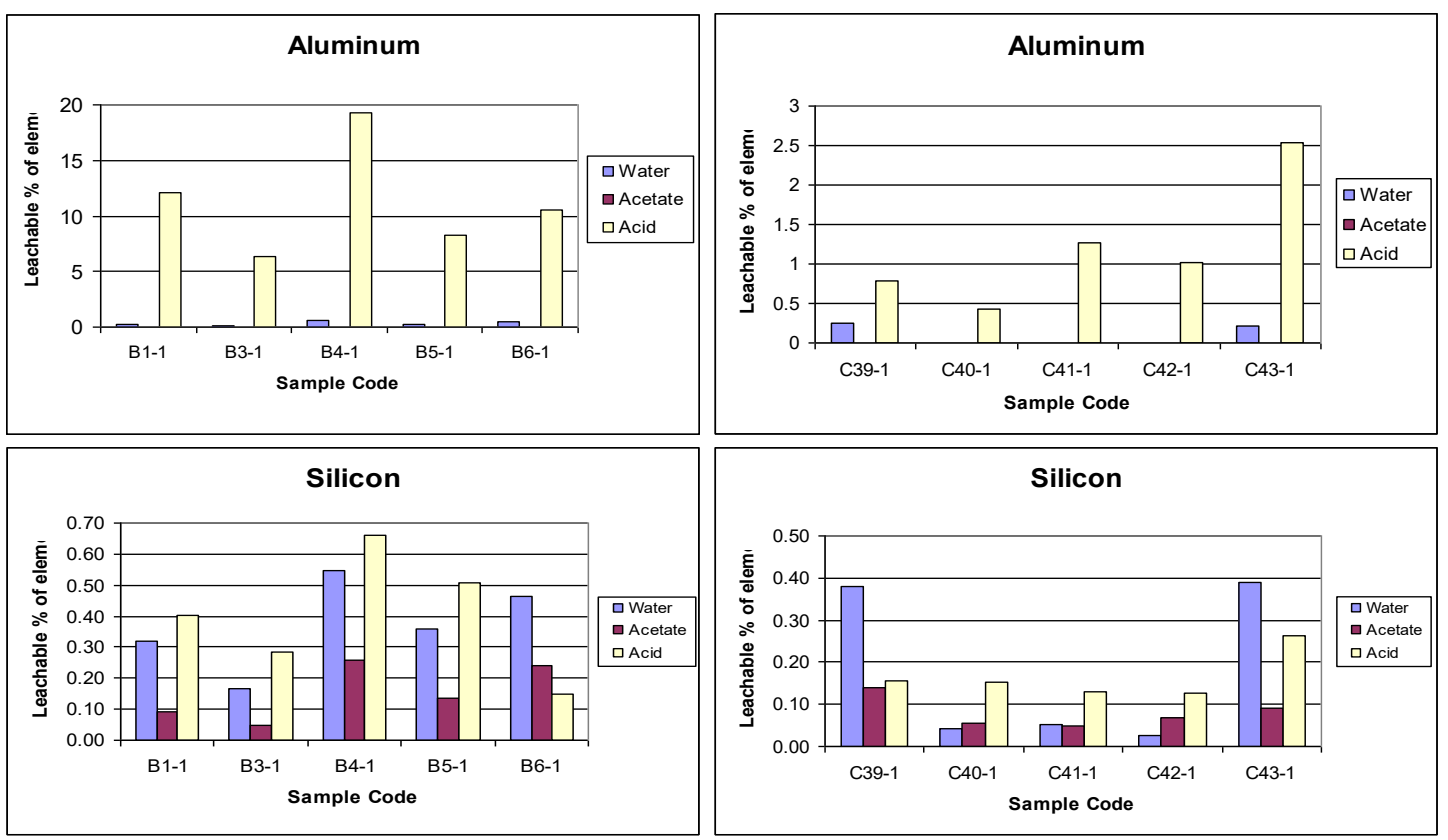

Figure 3. Proportions $\mathrm{Al}$ and Si released from the B and C seams by the different leaching processes.

Most of the $\mathrm{Ca}$ in the Bukit Asam coals also appears to be mobile (Table 2 and 3 ). In the $\mathrm{B}$ seam, $\mathrm{Ca}$ is mostly soluble in acid and exchangeable with the acetate. Only minor proportion of the total Ca present in the coal samples is removed by the waterwashing process (Figure 4). For $\mathrm{Ca}$, similar mode of occurrence was observed throughout the vertical section of the $B$ seam while a range of behavior patterns are noticed in the vertical section of the $C$ seam (Figure 4). In general, most of the mobile $\mathrm{Ca}$ in the $\mathrm{C}$ seam at Bukit Asam is removed by water washing and acetate solution, with only a small proportion was acid-soluble. Ca released into the acetate solution was likely represents material retained mainly in an exchangeable association with the organic matter, while the acid-soluble $\mathrm{Ca}$ may represent material present in carbonate form (Ward, 1992). Nevertheless, ammonium acetate solutions, may also release $\mathrm{Ca}$ held in carbonate form (Ward, 1992). In the absence of significant carbonate minerals, acid soluble calcium may be liberated from gypsum as it dehydrates to bassanite on plasma ashing. Ca can also be derived from calcium bound in an acid-soluble chelate form (Ward, 1992). Alternatelly, it may derived from calcite found in the raw coal mineral matter, or from mineral artifacts that formed from the interaction of organically associated $\mathrm{Ca}$ and $\mathrm{S}$ during the ashing process.
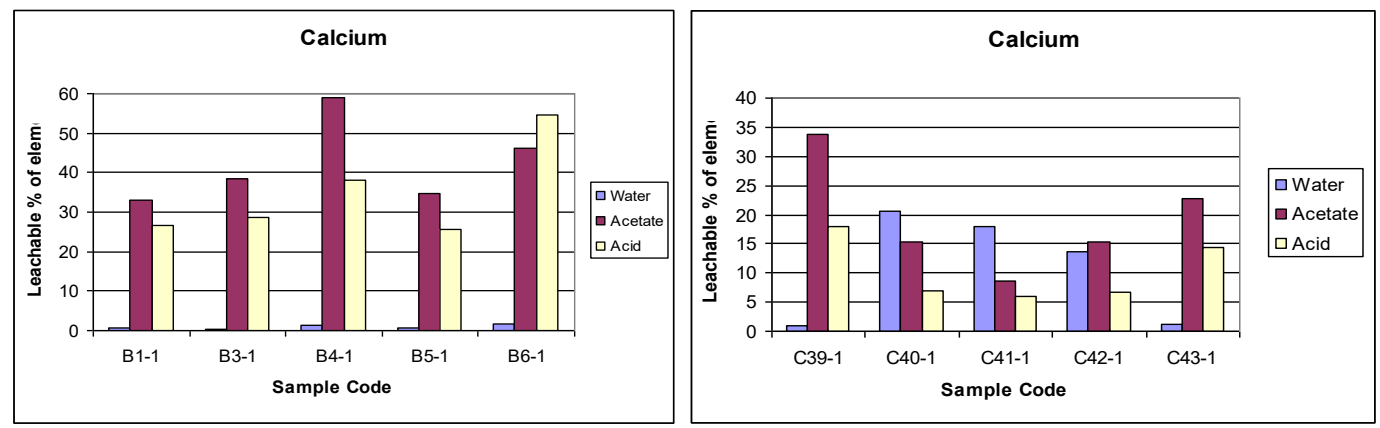

Figure 4. Proportions of $C$ a released from the $B$ and $C$ seams by the different leaching processes. 
Almost all of the mobile Fe observed in this study, occured in acid-soluble form (Figure 5). A very small amount of Fe was also released from the Bukit Asam coals with water washing. It has been suggested that the increasing mobility of Fe observed in water washing may relate to pyrite oxidation due to exposure during mining or storage (Ward, 1991), while the mobile Fe liberated by the subsequent acid treatment, without any accompanying $S$, was likely represents removal of Fe held in organometallic complexes (chelates) within the organic matter (Miller and Given, 1978, Ward (1991).
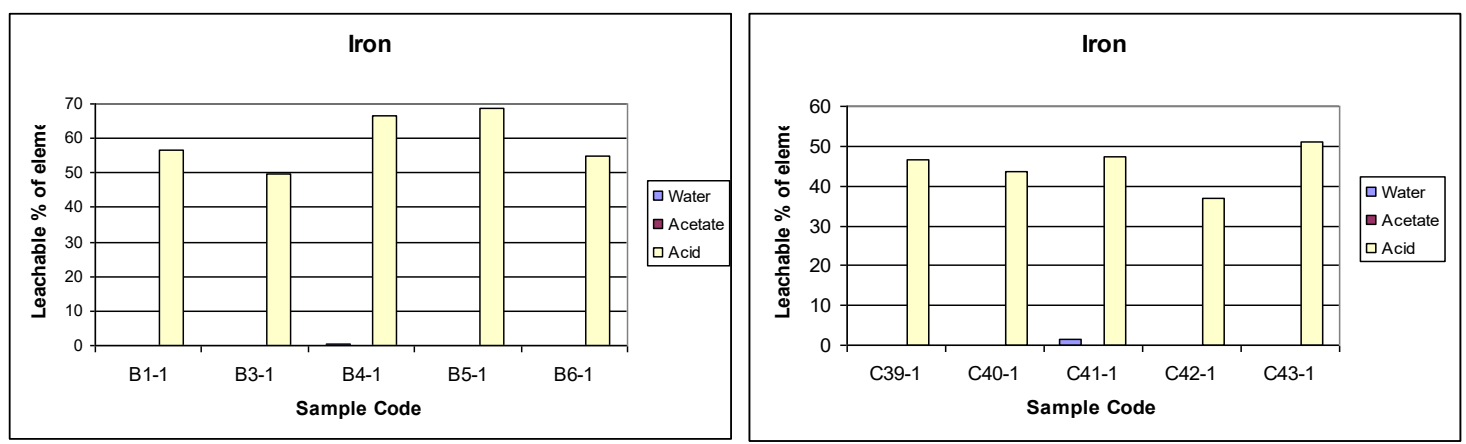

Figure 5. Proportions of Fe released from the $B$ and $C$ seams by the different leaching processes.

$\mathrm{Na}$ also appears to be mobile (Figure 6). Water washing and ammonium acetate treatment were found to remove almost all of the $\mathrm{Na}$ in the $\mathrm{B}$ seam, whereas in the $\mathrm{C}$ seam, water washing alone was sufficient to release most of the mobile Na present. The water-soluble sodium is presumably associated with colloidal suspensions of humic material, suggesting the occurrence of organically bound $\mathrm{Na}$ (Durie, 1961). In this study, the total quantity of mobile $\mathrm{Na}$ in some samples appeared to be greater than that originally present in the respective raw coal materials indicated by $\mathrm{XRF}$ analysis. It was likely that the wholecoal XRF method used in this study, was under-estimated the $\mathrm{Na}$ content of the coal samples. However the Na mobility pattern observed in this study is still consistent with the forms of $\mathrm{Na}$ mobility indicated by other similar studies (eg. Ward, 1991 and 1992).
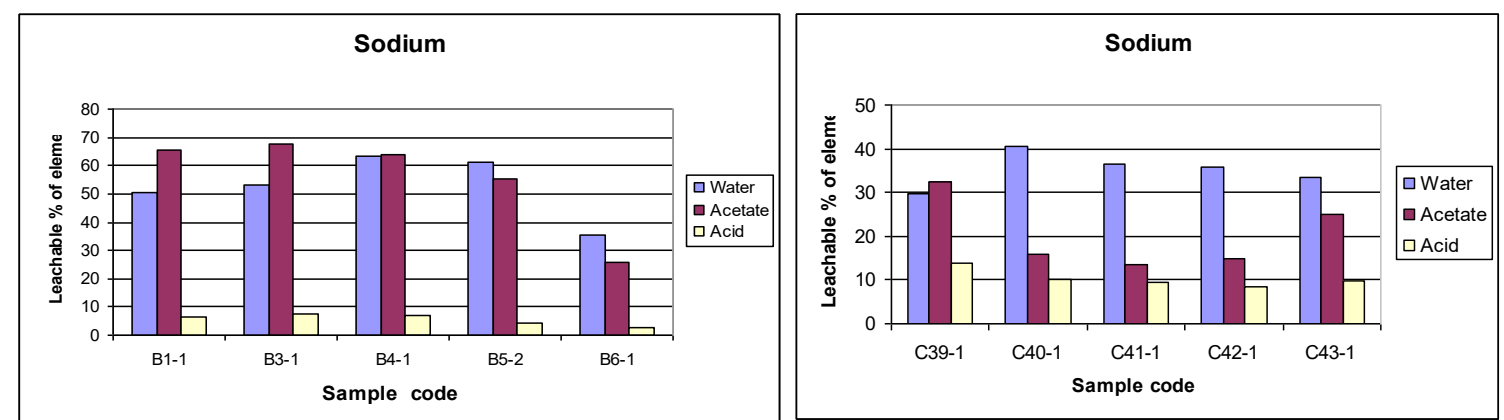

Figure 6. Proportions of $\mathrm{Na}$ released from the $\mathrm{B}$ and $\mathrm{C}$ seams by the different leaching processes.

The total quantity of $\mathrm{Mg}$ extracted by different leaching treatment is also higher than that indicated by whole-coal XRF analysis (Table 2 and 3 ). Despite the probable error involved, the results of the leaching tests still provide useful information about the mode of occurrence of $\mathrm{Mg}$ in the Bukit Asam coals. Most of the mobile $\mathrm{Mg}$ in $\mathrm{B}$ seam is present as exchangeable ions released by the ammonium acetate solution, with some also being in acid soluble form (Figure 7). 
$\mathrm{Mg}$ in the B seam is also insoluble in water, with only a very small quantity being released by the water-washing process. In $\mathrm{C}$ seam samples, a large proportion of the $\mathrm{Mg}$ was released by the ammonium acetate treatment, which suggests that the $\mathrm{Mg}$ is mostly present in ion-exchangeable form. A significant quantity of acid soluble Mg may suggests the occurrence of a Mg-bearing carbonate mineral (Ward, 1992).
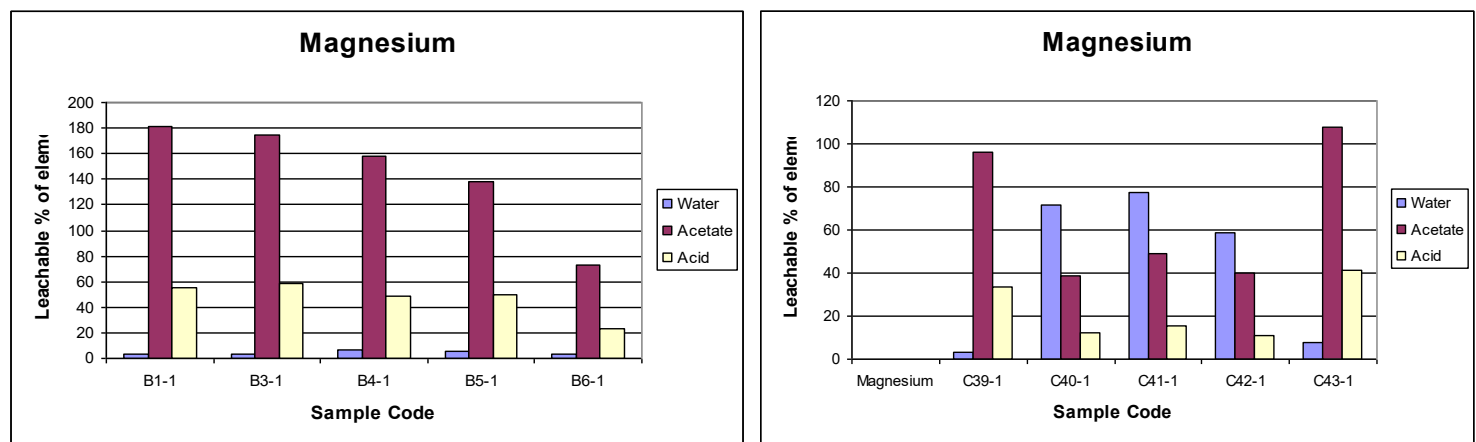

Figure. 7. Proportions of $\mathrm{Mg}$ released from the $\mathrm{B}$ and $\mathrm{C}$ seams by the different leaching processes.

\section{MINERALS IN LEACHED COAL RESIDUES}

The minerals identified by $\mathrm{X}$-ray diffraction in the LTA of the raw and leached coal samples are summarized in Table 4. Overall, the LTA percentages of the leached coals are slightly lower than those of the equivalent un-leached coal samples. While significant amount of the sulphate minerals (bassanite, coquimbite, hexahydrite, jarosite and alunogen) present in the raw coal LTAs, the LTAs of the leached coals, contain only insignificant proportions of bassanite and coquimbite.

The bassanite $\left(\mathrm{CaSO}_{4} \cdot 1 / 2 \mathrm{H}_{2} \mathrm{O}\right)$ and coquimbite $\left(\mathrm{Fe}_{2}\left(\mathrm{SO}_{4}\right)_{3} .9 \mathrm{H}_{2} \mathrm{O}\right)$ in the LTAs of the leached coal samples are thought, to be artifacts of the plasma ashing process (eg.. Ward, 1991, 1992). The elements involved were probably combined in the coal in an organic association that was not affected by water washing, ion exchange or acid solution (Ward, 1991). As bassanite in coal is believed to be derived from interaction between organically-bound (or mobile $\mathrm{Ca}$ ) and the organic sulfur in the course of the ashing process, the small amount of this mineral in the LTA of the treated coal samples was likely a result of removal of most $\mathrm{Ca}$ by the leaching treatments.

Pyrite is present in all of the raw coal LTAs from the $C$ seam, but is only present in the LTA of one leached coal sample (C41), with the concentration being less than in the equivalent untreated sample. The decreased concentration or absence of this mineral in the coal samples studied is thought to be related to pyrite oxidation during storage prior to the leaching study. Pyite is insoluble in $\mathrm{HCl}$, as such it was unlikely to be dissolved by the acid treatment.

Calcite is only identified in one leached coal sample (C43), and at a concentration less than that in the LTA of the corresponding untreated sample. Since the bulk of the $\mathrm{Ca}$ in the Bukit Asam coal samples is mobile, it was likely that calcite crystals deeply embedded in the coal pores which hardly reached by the leaching solutions. 


\section{MAKALAH ILMIAH}

Table 4. The XRD analysis of raw coal and treated coal LTAs.

B seam Minerals in raw coal LTAs

\begin{tabular}{|c|c|c|c|c|c|c|c|c|c|c|c|c|c|c|c|}
\hline $\begin{array}{l}0 \\
\frac{0}{0} \\
\varepsilon \\
\Phi \\
\infty \\
0 \\
\mathcal{Z}\end{array}$ & $\stackrel{\circ}{\stackrel{\circ}{ \pm}}$ & $\begin{array}{l}0 \\
\frac{N}{\sigma} \\
0 \\
0 \\
\end{array}$ & 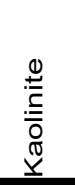 & $\begin{array}{l}\frac{0}{0} \\
\frac{0}{\pi} \\
0 \\
\end{array}$ & $\begin{array}{l}\frac{0}{0} \\
\frac{1}{0} \\
\frac{0}{\infty}\end{array}$ & 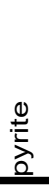 & 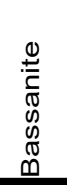 & 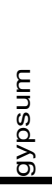 & 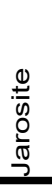 & 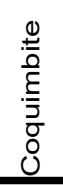 & 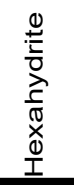 & 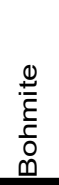 & $\begin{array}{l}\frac{c}{d} \\
0 \\
0 \\
0 \\
0 \\
\frac{5}{5} \\
\frac{5}{4}\end{array}$ & 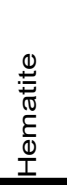 & 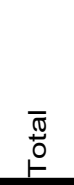 \\
\hline B1-1 & 7,2 & 11.0 & 80.4 & & & & 2.6 & & & & 6.4 & & & & 100.0 \\
\hline B3-1 & 5.2 & 3.3 & 62.1 & & & & 10.1 & & & & 9.1 & & 12.0 & 3.7 & 100.3 \\
\hline B4-1 & 6.6 & 3.5 & 67.5 & 0.5 & & & 4.3 & & & & 17.6 & 0.5 & 6.5 & & 100.4 \\
\hline B5-1 & 4.9 & 6.6 & 69.3 & & & & 13.0 & & & & 9.4 & & & & 100.0 \\
\hline B6-1 & 3.9 & 1.3 & 49.7 & 5.1 & & & 11.8 & & & 3.5 & 23.7 & 5.0 & & & 100.0 \\
\hline
\end{tabular}

B seam Minerals in leached coal LTAs

\begin{tabular}{|c|c|c|c|c|c|c|c|c|c|c|c|c|c|c|c|}
\hline B4-1 & 3.6 & 7.4 & 88.9 & & & & 3.7 & & & & & & & & 100.0 \\
\hline B5-1 & 3.6 & 2.8 & 92.9 & & & & 4.3 & & & & & & & & 100.0 \\
\hline B6-1 & 1.8 & 3.9 & 92.1 & 1.4 & & & 2.6 & & & & & & & & 100.0 \\
\hline 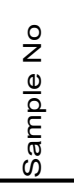 & $\stackrel{\leftrightarrows}{\leftrightarrows}$ & 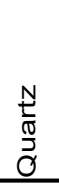 & 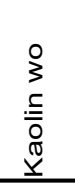 & $\begin{array}{l}\frac{\tilde{U}}{0} \\
\frac{0}{\pi} \\
0\end{array}$ & 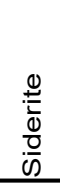 & 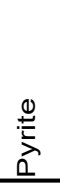 & 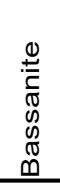 & $\begin{array}{l}\varepsilon \\
\overline{0} \\
0 \\
\hat{\lambda} \\
0\end{array}$ & $\begin{array}{l}\stackrel{0}{0} \\
\frac{1}{0} \\
\frac{0}{0} \\
\end{array}$ & 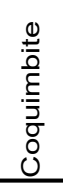 & 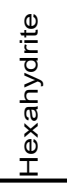 & 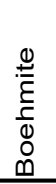 & $\begin{array}{l}\frac{c}{0} \\
0 \\
0 \\
\frac{0}{3} \\
\frac{5}{\alpha}\end{array}$ & 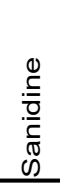 & $\begin{array}{l}\bar{\sigma} \\
\stackrel{0}{0}\end{array}$ \\
\hline C39 & 5.1 & 8.3 & 77.2 & 1.1 & 2.7 & 2.5 & 4.7 & & & & 2.7 & & & & 99.2 \\
\hline
\end{tabular}

C seam Minerals in raw coal LTAs

\begin{tabular}{|c|c|c|c|c|c|c|c|c|c|c|c|c|c|c|c|}
\hline $\begin{array}{l}0 \\
z \\
0 \\
\frac{0}{0} \\
\frac{\sigma}{0} \\
\omega\end{array}$ & $\leftrightarrows$ & $\begin{array}{l}\frac{N}{0} \\
\stackrel{0}{3} \\
0\end{array}$ & 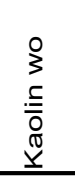 & $\begin{array}{l}\frac{0}{0} \\
\frac{0}{\pi} \\
0\end{array}$ & $\begin{array}{l}\frac{0}{0} \\
\frac{0}{0} \\
\frac{0}{0} \\
0\end{array}$ & 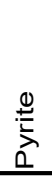 & 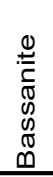 & $\begin{array}{l}\frac{E}{5} \\
0 \\
0 \\
0 \\
0 \\
0\end{array}$ & $\begin{array}{l}\frac{0}{0} \\
\frac{1}{0} \\
\frac{0}{\sigma} \\
\frac{7}{2}\end{array}$ & $\begin{array}{l}0 \\
\stackrel{0}{0} \\
\frac{1}{5} \\
\overline{0} \\
0 \\
0\end{array}$ & 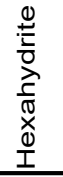 & 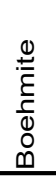 & 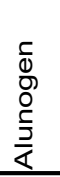 & 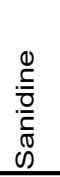 & 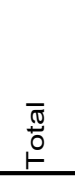 \\
\hline C39-1 & 5.1 & 8.3 & 77.2 & 1.1 & 2.7 & 2.5 & 4.7 & & & & 2.7 & & & & 99.2 \\
\hline C40-1 & 9.2 & 6.6 & 77.6 & 1.9 & 2.5 & 0.2 & 3.6 & & & 0.8 & 7.0 & & & & 100.2 \\
\hline C41-1 & 5.6 & 1.8 & 65.0 & 1.8 & & 2.8 & 5.4 & & & & 9.1 & & 14.0 & & 99.9 \\
\hline C42-1 & 6.0 & 4.1 & 70.2 & 1.4 & 2.2 & 1.7 & 5.9 & & & 1.0 & 2.5 & & 10.9 & & 99.9 \\
\hline C43-1 & 5.4 & 4.5 & 69.4 & 2.4 & 2.9 & 0.2 & 6.2 & & & & 14.6 & & & & 100.2 \\
\hline
\end{tabular}

C seam Minerals in leached coal LTAs

\begin{tabular}{|c|c|c|c|c|c|c|c|c|c|c|c|c|c|c|c|}
\hline $\begin{array}{l}0 \\
z \\
\frac{0}{0} \\
\frac{\varepsilon}{\sigma} \\
\infty \\
0\end{array}$ & $\stackrel{\leftrightarrows}{\leftrightarrows}$ & $\begin{array}{l}\frac{N}{2} \\
\frac{\pi}{3} \\
0 \\
\end{array}$ & 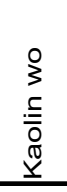 & $\begin{array}{l}\frac{\mathscr{U}}{0} \\
\frac{0}{\pi} \\
0\end{array}$ & $\begin{array}{l}\stackrel{0}{0} \\
\stackrel{0}{0} \\
\frac{0}{0} \\
\dot{\omega}\end{array}$ & 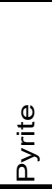 & $\begin{array}{l}\mathbb{0} \\
\stackrel{ \pm}{=} \\
\mathbb{0} \\
0 \\
0 \\
0 \\
0 \\
\end{array}$ & 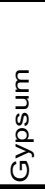 & 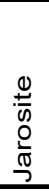 & 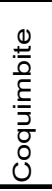 & 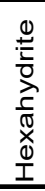 & 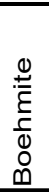 & $\begin{array}{l}\bar{\sigma} \\
\overline{0} \\
0 \\
\frac{0}{\alpha} \\
\frac{5}{\alpha}\end{array}$ & 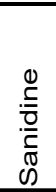 & $\begin{array}{l}\bar{\pi} \\
\stackrel{0}{0}\end{array}$ \\
\hline C39-1 & 3.7 & & & & & & & & & & & & & & \\
\hline C40-1 & 7.0 & 6.1 & 90.8 & & 1.9 & & 0.5 & & & 0.6 & & & & & 99.9 \\
\hline C41-1 & 6.8 & 2.0 & 95.0 & & & 1.7 & 1.5 & & & & & & & & 100.0 \\
\hline C42-1 & 4.3 & 4.3 & 89.1 & & 2.2 & & 2.5 & & & 2.0 & & & & & 100.1 \\
\hline C43-1 & 4.4 & 4.7 & 88.3 & 1.0 & 2.4 & & 2.1 & & 1.6 & & & & & & 100.1 \\
\hline
\end{tabular}




\section{OCCURRENCE OF INORGANIC ELEMENTS IN MACERALS OF BUKIT ASAM COALS}

The result of electron microprobe analysis appears in Table 5 and 6 . Overall, the macerals in low rank coals were found to have low but significant proportions of $\mathrm{Al}$, $\mathrm{Ca}$ and $\mathrm{Fe}$ which is in agreement with the result of selective leaching study. Both analysis showed lower concentrations of $\mathrm{Al}, \mathrm{Ca}$ and $\mathrm{Fe}$ in the high rank samples in comparison to low rank samples. However, the behavior of those elements in the high rank coals is somewhat similar to that of the low rank coals. Al and $\mathrm{Fe}$ were only removed from all of the coals by acid treatment, whereas $\mathrm{Ca}$ was liberated by all of the three treatments.

Table 5. Elemental composition of macerals by electron microprobe analysis

\begin{tabular}{|c|c|c|c|c|c|c|c|c|c|c|c|}
\hline $\begin{array}{l}\text { Sam } \\
\text { ple }\end{array}$ & Seam & Rank & Points & $\mathrm{C} \%$ & N\% & O\% & $\mathrm{Al} \%$ & $\mathrm{Si} \%$ & S\% & $\mathrm{Ca} \%$ & $\mathrm{Fe} \%$ \\
\hline $\begin{array}{l}\text { Frid1- } \\
\text { Tc }\end{array}$ & C & 0.49 & 20 & 72.71 & 2.6 & 18.08 & 0.11 & 0.04 & 0.96 & 0.1 & 0.05 \\
\hline $\begin{array}{l}\text { Frid3- } \\
\text { Tc }\end{array}$ & C & 2.30 & 2 & 88.99 & 0.72 & 5.02 & 0.12 & 0.01 & 1.66 & 0 & 0.04 \\
\hline $\begin{array}{l}\text { Frid3- } \\
\text { Sf }\end{array}$ & & & 5 & 89.25 & 1.65 & 4.44 & 0.01 & 0.01 & 1.57 & 0.01 & 0.03 \\
\hline $\begin{array}{l}\text { Frid4- } \\
\text { Tc }\end{array}$ & $B$ & 0.54 & 9 & 71.04 & 1.57 & 19.78 & 0.11 & 0.02 & 0.73 & 0.22 & 0.06 \\
\hline $\begin{array}{l}\text { Frid4- } \\
\text { Dsc }\end{array}$ & & & 3 & 75.52 & 1.46 & 14.65 & 0.08 & 0.03 & 0.88 & 0.21 & 0.06 \\
\hline $\begin{array}{l}\text { Frid4- } \\
\text { Glv }\end{array}$ & & & 2 & 70.64 & 1.92 & 19.76 & 0.06 & 0.01 & 0.69 & 0.14 & 0.06 \\
\hline $\begin{array}{l}\text { Frid4- } \\
\text { Sub }\end{array}$ & & & 3 & 72.61 & 0.93 & 18.46 & 0.08 & 0.01 & 0.71 & 0.07 & 0.11 \\
\hline $\begin{array}{l}\text { Frid4- } \\
\text { Sf }\end{array}$ & & & 11 & 75.26 & 1.4 & 16.16 & 0.06 & 0.05 & 0.74 & 0.1 & 0.02 \\
\hline $\begin{array}{l}\text { Frid5- } \\
\text { Tc }\end{array}$ & B & 2.45 & 8 & 87.93 & 1.48 & 6.18 & 0.01 & 0.01 & 1.56 & 0.01 & 0.01 \\
\hline $\begin{array}{l}\text { Frid5- } \\
\text { Sf }\end{array}$ & & & 4 & 88.9 & 1.49 & 5.09 & 0 & 0.01 & 1.58 & 0.03 & 0.05 \\
\hline $\begin{array}{l}\text { Frid5- } \\
\text { Sc }\end{array}$ & & & 2 & 85.8 & 1.54 & 5.14 & 0 & 0.11 & 1.41 & 0.05 & 0.06 \\
\hline
\end{tabular}

Table 6. Comparison of electron microprobe data with results of selective leaching analysis

\begin{tabular}{lllll}
\hline Seam & Frid1 & Frid3 & Frid4 & Frid5 \\
\cline { 2 - 5 } & C & C & B & B \\
& seam & seam & seam & seam \\
\hline Rank (Rvmax) & $0.68 \%$ & $2.3 \%$ & $0.64 \%$ & $2.45 \%$ \\
\hline Aluminum - H2O & 2.00 & Bld & 3.00 & Bld \\
\hline Aluminum - NH4Ac & Bld & Bld & bld & Bld \\
\hline Aluminum - HCl & 199.00 & 28.00 & 160.00 & 19.00 \\
\hline Mobile Al (ppm) & 202.00 & 28.00 & 163.00 & 19.00 \\
\hline Mobile Al (\%) & 0.02 & 0.00 & 0.02 & 0.00 \\
\hline Aluminum minerals & & & & \\
\hline Aluminum in Tellocolinite & 0.11 & 0.12 & 0.11 & 0.01 \\
\hline
\end{tabular}




\begin{tabular}{lllll}
\hline Calcium - H2O & 57.00 & 84.00 & 51.00 & 179.00 \\
\hline Calcium - NH4Ac & 85.00 & 49.00 & 535.00 & 26.00 \\
\hline Calcium - HCl & 84.00 & 24.00 & 392.00 & 13.00 \\
\hline Mobile Ca (ppm) & 226.00 & 156.00 & 978.00 & 217.00 \\
\hline Mobile Ca (\%) & 0.02 & 0.02 & 0.10 & 0.02 \\
\hline Calcium minerals & & & & \\
\hline Calcium in Tellocolinite & 0.10 & 0.00 & 0.22 & 0.01 \\
\hline Iron - H2O & Bld & Bld & bld & Bld \\
\hline Iron - NH4Ac & Bld & Bld & bld & Bld \\
\hline Iron - HCl & 255.00 & 155.00 & 265.00 & 270.00 \\
\hline Mobile Fe (ppm) & 255.00 & 155.00 & 265.00 & 270.00 \\
\hline Mobile Fe (\%) & 0.03 & 0.02 & 0.03 & 0.03 \\
\hline Iron Minerals & & & & \\
\hline Iron in Tellocollinite & 0.05 & 0.04 & 0.06 & 0.01 \\
\hline
\end{tabular}

Very small concentrations of $\mathrm{Al}, \mathrm{Ca}$ and $\mathrm{Fe}$ are also present in high rank coal. Overall the concentration of those element are less than in the macerals of the equivalent low rank coal samples. The microprobe study also indicates a decrease in the proportion of $\mathrm{Ca}$ and $\mathrm{Al}$ in the macerals of corresponding coals from low rank to high rank. In contrast, the increasing sulphur contents were observed in all of the macerals in the high rank coals, compared to the corresponding low rank samples, suggesting the retention of $S$ present in the organic matter.

\section{ROLE OF NON-MINERAL INORGANIC ELEMENTS IN METAMORPHISM OF COAL MINERALS}

It has been suggested that the the nonmineral inorganics from coal will decreased in proportion with rank advance (Ward, 2002). Thus, if these constituents still persist in higher rank coals, they are typically present in relatively low proportions. However, the artifact minerals still present in significant concentrations (average $10.3 \%$ ) in the LTA of the highrank coals at Bukit Asam (Susilawati and Ward, 2002). As such it was likely that the inorganic elements are still relatively abundant in the mineral matter of the higher-rank coals of Bukit Asam. Since the mineral forming reactions in the heated coals at Bukit Asam required the presence of such particular elements (see Susilawati and Ward., 2002), it is likely that the source of that elements are from non-mineral inorganic elements originally present in the high rank coal. Further study, however, is needed to investigate more fully the role of inorganic elements in metamorphism of the Bukit Asam coal seams.

\section{COMPARISON BETWEEN SEAMS}

Although present in very small concentrations, the inorganic constituents of Bukit Asam coal respond to the various leaching treatments and exhibit similar behaviour to the inorganic elements in the low rank coal of South Australia (Ward, 1992) and the lignites of northern Thailand (Ward, 1991). In general, the B seam has more mobile elements than the $C$ seam coal. Over half of the $\mathrm{Ca}$ and $\mathrm{Fe}$ in the $\mathrm{B}$ seam samples studied are mobilized by a combination of acetate and acid treatment. By contrast, less than $50 \%$ of the $\mathrm{Ca}$ and $\mathrm{Fe}$ are mobile in the $\mathrm{C}$ seam samples studied. The $\mathrm{Ca}$ in the $\mathrm{C}$ seam also appears to occur mainly in solution in the pore water instead of as exchangeable components of the carboxylates in the organic matter. Moreover, whereas all $\mathrm{Na}$ was removed from the $B$ seam coal by water and acetate treatment, only $60-70 \%$ of the $\mathrm{Na}$ was liberated from the $\mathrm{C}$ seam coal. $\mathrm{Na}$ in the $\mathrm{C}$ seam mostly occurs as a water-soluble component, suggesting that most of the $\mathrm{Na}$ in the $\mathrm{C}$ seam coal probably occurs as dissolved ions in the pore water. 
The difference between the two seams may reflect differences in the composition of the water permeating the respective seams during their geological history (Ward, 1992). The actual concentrations of the elements in in-situ coal samples, may depend partly on the composition of the water that in contact with the coal bed (Ward., 1992). Upward flow of saline water, for instance, may introduce some inorganic elements to the coal, some of which possibly migrated higher into the coal seam than others, leading to isolation of different elements at different levels within the seam section (Brockway and Borsaru, 1985).

\section{CONCLUSIONS}

Selective leaching studies, combined with low temperature ashing, can be used to identify both the minerals and the nonmineral inorganics in the low and high rank coals from Bukit Asam. The inorganic elements in the low rank coals of the $B$ and $C$ seams at Bukit Asam comprise three different inorganic fractions; water soluble, ion-exchangeable and acid soluble elements.

Small but significant concentrations of inorganic elements (Al, $\mathrm{Ca}$ and $\mathrm{Fe}$ ) occur in the individual macerals of Bukit Asam coal, including both sub-bituminous and semi-anthracite materials. There is an indication that some of the elements, particularly the $\mathrm{Ca}$ and $\mathrm{Al}$ present in the low rank coals, are lost from the organic matter with increases in the rank of the coals concerned.

The inorganic elements in Bukit Asam coal may also provide a significant contribution to the formation of new minerals in the coal, due to localized heat flow from igneous intrusive bodies.

\section{ACKNOWLEDGMENTS}

Thanks are expressed to Australian Develoment Scholarship 2001 for funding to this study and PT Bukit Asam for their generous assistance with the field work.
The author is gratefully acknowledged Prof Colin Ward for his supervision and guidance during the completion of this study. The author also thank Irine Wainwright for her assistance in Xrf analysis and Zong Seng $\mathrm{Li}$ for his assistance in selective leaching and electron microprobe analysis.

\section{References:}

Benson, S.A., Holm, P.L., 1985. Composition of inorganic constituents in three low-rank coals. Industrial and Engineering Chemistry Fundamentals Product Research and Development 24, 145-149.

Bohor, B.F., Triplehorn, D.M., 1993. Tonsteins: altered volcanic-ash layers in coal-bearing sequences., Geological Society of America Special Paper, p44.

Bustin, R.M., Mastalerz, M., Wilks, K.R., 1993. Direct determi-nation of carbon, oxygen and nitrogen content in coal using the electron microprobe. Fuel 72, 181 185.

De Coster, G.L., 1974. The geology of the Central and South Sumatra Basins, Indonesian Petroleum Association , 3th Annual Convention, pp. 77-110.

Finkelman, R.B., 1994. Abundance, source and mode of occurrence of the inorganic constituents in coal, in: Kural, $\mathrm{O}$. (Ed.), Coal. Istanbul Technical University, Istanbul, 115-125.

Finkelman, R.B., Bostick, N.H., Dulong, F.T., Senftle, F.E., Thorpe, A.N., 1998. Influence of an igneous intrusion on the inorganic geochemistry of a bituminous coal from Pitkin County, Colorado. Int.J. Coal Geol 36, 223-241.

Gluskoster, H.J., 1965. Electronic low temperature ashing of bituminous coal. Fuel, 44: 285-291.

Gurba, L.W. and Colin, R.W., 2000. Elemental composition of coal macerals in 
relation to vitrinite reflectance, Gunedah Basin, Australia, as determined by electron micropobe analysis. International Journal of Coal Geology, 44: 127-147.

Harvey, R., D. , Ruch, R., R. , 1986. Mineral Matter in Illinois and Other U.S. Coals, Mineral Matter and Ash in Coal. American Chemical Society, 10-40.

Hutchison, C.S., 1989. Geological evolution of Southeast Asia. Oxford University Press, New York, 333 pp.

Kemezys, M., Taylor, G.H., 1964. Occurrence and distribution of minerals in some Australian coals. J. Inst. Fuel 37, 389-397.

Kiss, L.T., King, T.N., 1977. The expression of results of coal analysis: the case for brown coals. Fuel 56, 340-341.

Kiss, L.T., King, T.N., 1979. Reporting of low-rank coal analysis - the distinction between minerals and inorganics. Fuel 58, 547-549.

Koesoemadinata, R.P., 1978. Sedimentary framework of Tertiary coal basins in Indonesia, 3rd Regional Conference on Geology and Mineral Resources of South East Asia, Bangkok, Thailand, pp. 621639.

Li, Z., Moore, T.A., Weaver, S.D., 2001. Leaching of inorganics in the Cretaceous Greymouth coal beds, South Island, New Zealand. Int.J. Coal Geol 47, 235-253.

Li, Z., Ward, C.R., Gurba, L.W., 2010. Occurrence of non-mineral inorganic elements in macerals of low-rank coals. Int.J. Coal Geol 81, 242-250.

Matasak, Th., Kendarsi, R., 1980. Geologi endapan batubara di Bukit Asam Sumatra Selatan, Buletin Departemen Geologi. Institut Teknologi Bandung 1, 1133

Mastalerz, M., Gurba, L.W., 2001. Determination of nitrogen in coalmacerals using electron microprobe techniqueexperimental procedure. International Journal of Coal Geology 47, 23 - 30

Norrish, K. and Chappell, B. W. (1977) Xray fluorescence spectrography: in Physical Methods in Determinative Mineralogy, J. Zussman, ed., Academic Press, New York, 720p.

Pujobroto, A., 1997. Organic petrology and geochemistry of Bukit Asam coal, South Sumatra, Indonesia. Ph.D Thesis, The University of Wollongong, Wollongong.

Stalder, P., 1976. A review of the South Sumatra Coal Basin, Shell Minjbuow, N.V, (unpublished), Jakarta.

Susilawati, R., Ward, C.R., 2006. Metamorphism of mineral matter in coal from the Bukit Asam deposit, South Sumatra, Indonesia. Int.J. Coal Geol 68, 171-195.

Taylor, J.C., 1991. Computer programs for standardless quantitativeanalysis of minerals using the full powder diffraction profile. Powder Diffraction 6, 2 - 9 .

Ward, C.R., 1989. Minerals in bituminous coals of the Sydney basin (Australia) and the Illinois basin (U.S.A.). Int.J. Coal Geol 13, 455-479.

Ward, C.R., 1991. Mineral Matter in LowRank Coals and Associated Strata of the Mae Moh Basin, Northern Thailand. Int.J. Coal Geol 17, 69-93.

Ward, C.R., 1992. Mineral Matter in Triassic and Tertiary Low-Rank Coals from South-Australia. Int.J. Coal Geol 20, 185208.

Ward, C.R., 2002. Analysis and significance of mineral matter in coal seams. Int.J. Coal Geol 50, 135-168.

Ward, C.R., Gurba, L.W., 1999. Chemical composition of macerals in bituminous coals of the Gunnedah Basin, Australia, using electron microprobe analysis 


\section{MAKALAH ILMIAH}

techniques. Int.J. Coal Geol 39, 279-300.

Ward, C.R., Warbrooke, P.R., Ivor Roberts, F., 1989. Geochemical and mineralogical changes in a coal seam due to contact metamorphism, Sydney Basin, New South Wales, Australia. Int.J. Coal
Geol 11, 105-125.

Ward, C.R., Taylor, J.C., Cohen, D.R., 1999. Quantitative mineralogy of sandstone $s$ by $X$-ray diffractometry and normative analysis. Journal of Sedimentary Research 69, 1050 - 1062.

$\begin{array}{ll}\text { Diterima } & : \text { 3 Juni } 2015 \\ \text { Direvisi } & : \text { 29 Juli } 2015 \\ \text { Disetujui } & : \text { 20 Agustus } 2015\end{array}$

